\title{
CHALLENGES IN LEGAL TRANSLATION - REVISITED
}

\section{INTRODUCTION}

It is commonplace that legal translation poses particular challenges even to experienced translators and a fortiori to less experienced translators. In this paper the challenges are described from a teacher's point of view ${ }^{1}$ and experience from evaluating the work of semi-professional translators, i.e. candidates sitting for the exam to become authorised translators in Norway, ${ }^{2}$ drawing on their ability to translate authentic texts. The required translation competence encompasses different sub-competences, i.a. transfer competence which Neubert rightly claims to be "the distinguishing domain of a translator" (Neubert 2000: 6). This presupposes that (s)he is able to adapt his/her translation strategy according to the purpose of the translation, i.e. the assignment of the client. The language pairs discussed here are Norwegian-German and/or Norwegian-English. The inclusion of the latter language pair is due to the usually much larger number of candidates translating into English than into German and thus giving more data to compare.

The rest of the paper is organized as follows: In section 2, the focus is on why legal translation is claimed to be so special compared to other LSP translations. In section 3, a delineation of legal texts is discussed based on selected relevant literature. In section 4 , the main reasons for the on-line course in legal translation are given. In the subsequent section some empirical findings are presented by way of illustration. The final section offers concluding remarks and outlook.

\section{2 “WHAT'S SO SPECIAL ABOUT LEGAL TRANSLATION?"3}

Legal translation is a specific type of translation for special-purpose (LSP translation) differing from other LSP-translations in that law is in the language (Gémar 1988: 313). Vanderlinden (1999: 73) therefore rightly argues "sans langue pas de droit, car il demeurerait à l'état de pensée et par conséquent incommunicable, donc inapplicable".

Author's address: Department of Professional and Intercultural Communication, NHH Norwegian School of Economics, Hellev. 30, 5045 Bergen, Norway. E-mail: ingrid.simonnas@nhh.no

1 Cf. also comparable studies on legal translation training by e.g. Hjort-Pedersen/Faber 2005 and Jermol 2012.

2 For a short description of the exam see http://www.nhh.no/en/research-faculty/department-ofprofessional-and-intercultural-communication/statsautorisert-translatøreksamen/the-nationaltranslator-accreditation-exam.aspx

3 Cf. Harvey's homonymous title of 2002. 
Legal translation is inherently linked to the particular legal culture of its source text which more often than not is different from the legal culture in the target text. This is commonly acknowledged and examples for the ensuing translation problems have been discussed in many publications. Such translation problems occur because each legal system/culture (Sunde 2010) has its specific conceptual structure. The differences between legal systems, e.g. legal institutions, judicial systems, and courtroom procedures, vary a lot, especially when Common law and Civil law are at stake. ${ }^{4}$ By way of illustration, the particular Norwegian legal institution of ODELSRETT is specific. This is not an inheritance right, but "a right to reclaim, not to inherit [the agricultural property]" (homepage of the Norwegian Agricultural Authority), ${ }^{5}$ and the translator has to use an appropriate translation strategy to overcome the gap between source (legal) culture and target (legal) culture.

\section{RELEVANT LEGAL TEXTS}

'Legal texts' is a broad category, which has to be defined more narrowly drawing on some classifications found in recent literature, keeping in mind that classifications are always made for a particular purpose. In the following I present some attempts at classification and finally opt for one of them.

Hickey (1998: 224) circumscribes legal texts in the following way:

[legal texts] usually make or amend the law or regulate relationships between persons, being informative, explicative and factual [...] often referring in specialised terminology and complex style to realities, concepts and distinctions that are not material, concrete or physical.

In this explication we find as demarcations: (1) the purpose of the text (making or amending the law or regulating relationships between persons), (2) the text type (being informative, [...]) echoing Reiß's text typology (Reiß 1969), (3) language use and style and (4) reference to declarative and encyclopaedic knowledge.

Busse (2000) differentiates nine classes of legal texts of which normative texts ("Texte mit normativer Kraft") such as statutes, rules and regulations and (2) texts that interpret a normative text ("Textsorten der Normtext-Auslegung") and (3) court decisions are the most relevant for our discussion.

The internationally renowned scholar Šarčević (2000: 11) proposes a division of legal texts into three categories according to their language function; those that are (1) primarily prescriptive, (2) primarily descriptive but also prescriptive and those that are (3) purely descriptive.

4 The civil law system is usually described as strictly codified laws, and derives its authority from codes and statutes. In this system, the judiciary plays the role solely of applying the law. On the other hand, Common law is defined as "the body of law developed in England primarily from judicial decisions based on custom and precedent, unwritten in statute or code, and constituting the basis of the English legal system and of the system in all of the United States except Louisiana" (Merriam-Webster online, emphasis added).

5 Lind in Gisle (2010: 282) proposes the following translation: “(Kan oversettes med:) allodial right(s), allodial entitlement". 
Harvey (2002: 178) argues for a broader definition and includes i.a. contracts, wills, court documents etc. "which are 'bread and butter' activities for lawyers and legal translators."

Simonnæs (2005) argues for the inclusion of legislative texts and judicial decisions because of their dual addressees and uses those text types for her analysis.

Tiersma (2012) differentiates between i.a. constitutions, statutes and private legal documents such as wills and certain types of contracts. Some of them are more often in need of being translated than others. I am not aware of a quantified study on this issue. I would however presume that private legal documents (birth certificates etc.) in particular are more often translated in today's globalized society where the purpose of such a translation is possibly to deploy its legal effect in the other country. At the same time, and again with reference to globalization and subsequent cross-border legal proceedings, translation of particular provision $(\mathrm{s})^{6}$ must be necessary for the purpose of giving insight into the legal culture/system of the source text and to produce a text that will lead to the same legal effects in practice (Šarčević 2000: 71, emphasis added; cf. Simonnæs 2006).

For the scope of this paper I find three particular categories very useful, based on their purpose, viz. (1) Busse's normative texts, in the literature often referred to as 'legislative texts', (2) texts that interpret a normative text and (3) judicial decisions, which according to Tiersma (s.a.) would all be characterized as "authoritative legal texts" whereas according to Šarčević's classification categories 1 and 2 would be of special interest here.

My working definition of legal text for the purpose of this paper is though slightly different from Hickey's definition cited above in also including texts that apply the law, viz. "legal text $=$ a text that makes, amends or applies the law". However, the definition should have the following supplementary remarks: In doing so the text regulates relationships between legal and natural persons. It often uses specialised terminology and is characterised by culture dependent style conventions.

The insight into the specialised legal terminology and concept systems as well as the knowledge of style conventions ${ }^{7}$ in different legal languages are of paramount importance and present the biggest problems for a translator. ${ }^{8}$ Space constraints however do not allow for comments on both topics in equal detail in this paper. However,

6 Cf. Mattila (2013: 22) who argues that Europe, being in a state of ongoing unification, "increasingly needs translation of legal texts" and continues to point out that "[t]he majority of these translations are very often done by linguist-translators" (ibid.). According to Mattila, "legal texts' include laws, judgments, administrative decisions, private documents etc.

7 Cf. Chroma (2008: 305) who rightly acknowledges the competence in the target language's specific legal style of writing being one of three prerequisites for the successful translation of legal texts.

8 Cf. the following comments on the homepage for Translated Norwegian legislation on the unofficial translation of the Norwegian Penal Code (Straffeloven 1902): "Finding exact English equivalents for the Norwegian legal terms and concepts involved was no easy task. In some cases the solutions adopted are no more than approximations, since there are no direct equivalents, and on occasion it has been necessary to resort to explanatory notes". 
in translator training they will be addressed in detail and other text types will also be used as examples.

\section{REASONS FOR THE ON-LINE COURSE IN LEGAL TRANSLATION, JURDIST}

There are different reasons for this on-line course. In contrast to different well developed study programs in other countries, Norway offers no formal translator training. At the same time NHH Norwegian School of Economics has had delegacy of the National Accreditation Exam for Translators (NTAE; translatøreksamen) since 1979. About 100 candidates sit this exam each year in a wide range of languages, but not surprisingly with a high failure rate (about $80 \%$ ). Part of the exam is the translation of a legal text which is often seen as the most difficult task. Together with the observation of recurrent challenges confronting the candidates in legal translation, these are the reasons why NHH has designed the on-line course in legal translation JurDist, which has been offered since August 2013. The languages are from Norwegian into French, German and Spanish, and vice versa, English to be added in the future. 37 candidates from Norway, different European countries and even from Australia attend the course. Their background knowledge in translation and legal knowledge is very heterogeneous. We focus on (1) general knowledge of legal cultures (Norwegian, contrasted to the French, German and Spanish legal culture), (2) introduction to relevant translation theories and (3) translation activities.

In the first of this two-semester course the main focus is on general introduction to the field of law with special focus on Norwegian law, always taking into consideration the aspect of why this knowledge is a conditio sine qua non for successful translations.

In translator training it is particularly important to focus on translation problems and different translation strategies to meet these problems. In legal translation one recurrent problem for translator (candidates) is to be aware of the possible conceptual differences between the legal systems involved which will strongly influence the translation product (see Fig. 1). Identifying and subsequently translating culture bound terms has proven to be particularly challenging; one reason being that the candidates are not sufficiently aware of the difference between a concept and a term ("verbal designation of a general concept in a specific field" - ISO 1087). Concepts that are specifically Norwegian with no counterparts in other legal systems and concepts that overlap more or less in these legal cultures, e.g. judicial institutions such as courts, are therefore used as examples for training purposes. Special focus on this is given in the general introduction to the field of law in the first part of the JurDist course and will be one of the main topics of the translation activities in the spring semester, dealing with different legal text types.

With respect to relevant translation theories our focus is geared towards the Skopos theory (Vermeer 1978) where translation is seen as a form of translational action based on a source text, and the functionalist approach as developed e.g. by Nord (1997). Following this approach, it is commonly acknowledged that the translator has to take into 
account i.a. the purpose and addressees of the (re)produced text, envisaged and usually revealed, in the client's explicit assignment. Nord defines 'translation' as "a form of mediated intercultural communication based on a source text" (Nord 1997: 18). In legal translation this includes the knowledge of the particular legal cultures involved as shown in the adapted schema of translation process (Schäffner 1998).

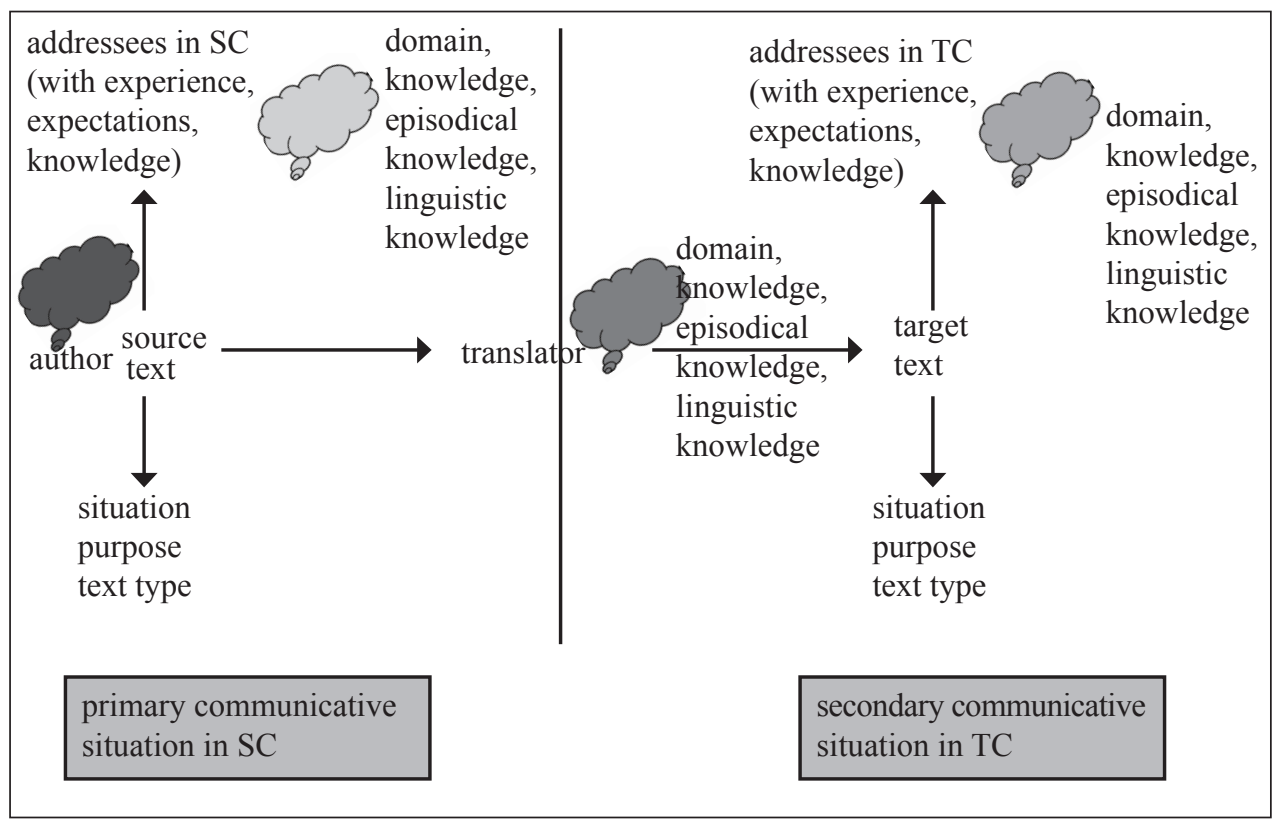

Fig. 1: Adaptation of schema of translation process (Schäffner 1998: 84)

In many cases the translator is a non-expert (e.g. in legal matters) and must translate a text written by an expert for a target language readership of experts. In Fig. 1 this is illustrated by the coloured balloons representing the cognitive forms of knowledge of the translator and the other actors in a translation situation. The different colours indicate that there may not be a total overlap between the author's and the translator's cognitive forms. Likewise the source text and target text addressee's cognitive forms may differ. These factors obviously have an impact on the translation process, product and the applicable translation strategy in what Lörscher (1991: 71) defines as a potentially conscious procedure for the solution of a problem which an individual is faced with when translating a text segment from one language to another.

\section{DISCUSSION}

The language pair under consideration is primarily Norwegian-German. My research and teaching interest for this language pair result from my experience in assessing the results from the NTAE in this language pair for about 25 years. Because the 
number of candidates translating between Norwegian and English is by far the highest and, as such, provides many more examples to discuss, examples from this language pair are also included in the discussion of empirical findings.

In this section I draw on selected examples in order to demonstrate what problems the candidates encounter in the exam and what solutions they opted for as well as whether these solutions were assessed as felicitous or not. These examples are in turn useful as pedagogical resources to help expand the knowledge of our JurDist candidates.

In the context of Norwegian-German legal translations the problems are less obvious because both legal systems are (heavily) influenced by Roman Law and share many fundamental similarities, but still the challenges remain when e.g. culture bound terms are to be translated.

\subsection{Culture bound (legal) terms}

In a court decision from one of the Norwegian courts of appeal, i.e. Borgarting lagmannsrett, the structure of the court system is accessible as the text indicates that the claimant does not accept the decision of the lower court, i.e. Oslo tingrett. When comparing the Norwegian and German legal system with respect to the court system, the candidate should know that the system of the so-called ordinary courts or courts of general jurisdiction (ordentliche Gerichte) consists of the Amtsgerichte (local courts) and the Landgerichte (regional courts) as courts of first instance. An appeal (Berufung) from the local court is heard by the Landgericht, whereas an appeal from the regional court is heard by the Oberlandesgericht. The Bundesgerichtshof (the Federal Court of Justice) is dealing with the so-called further appeal (Revision) (Hau 2011: 61ff.). In contrast the Norwegian court system has only one type of court of first instance, i.e. tingrett (district court). The court of appeal (ankedomstol) would be the lagmannsrett, and the court of last resort is the Høyesterett (Supreme Court). ${ }^{9}$

(1) In the English and German translation the following renditions are used for Oslo tingrett and Borgarting lagmannsrett respectively:

\begin{tabular}{|l|l|}
\hline English translation of Oslo tingrett & $\begin{array}{l}\text { Oslo tingrett (Oslo district court); Oslo } \\
\text { Municipal Court [Oslo tingrett]; Oslo High } \\
\text { Court*; the Oslo tingrett (court of original } \\
\text { jurisdiction); Oslo county Court*; Oslo } \\
\text { tingrett (the District Court); Oslo Law } \\
\text { Courts* }\end{array}$ \\
\hline German translation of Oslo tingrett & Amtsgericht in Oslo (Oslo tingrett) \\
\hline
\end{tabular}

9 Designations in English as proposed on the homepage of the Courts of Justice (Norges domstoler). See also Lind (2003: 5) and his discussion on the names of courts of law. For more details about the number and competences of these courts see the homepage. 


\begin{tabular}{|l|l|}
\hline $\begin{array}{l}\text { English translation of Borgarting } \\
\text { lagmannsrett }\end{array}$ & $\begin{array}{l}\text { Borgarting lagmannsrett [Borgarting Court } \\
\text { of Appeal - civic division]; Borgarting } \\
\text { lagmannsrett (the High Court) *; Borgarting } \\
\text { Court of Appeal; the Borgarting Court } \\
\text { of Appeal; Borgarting district court*; } \\
\text { Borgarting lagmannsrett (the High Court*); } \\
\text { Borgarting Court of Appeals; }\end{array}$ \\
\hline $\begin{array}{l}\text { German translation of Borgarting } \\
\text { lagmannsrett }\end{array}$ & $\begin{array}{l}\text { nächsthöheres Gericht in Oslo (Borgarting } \\
\text { lagmannsrett) }\end{array}$ \\
\hline
\end{tabular}

An asterisk indicates a translation that is not correct.

We can see that the candidates choose different strategies: Some use the original Norwegian designation with or without the definite article followed by a translation into English designating a functional equivalent; one candidate even gives supplementary information on the kind of proceedings the courts deals with in the present case: 'civic division'. Another candidate uses only an English translation Oslo High Court for the court of first instance, which is not correct and rather misleading, whereas yet another uses a combination of the English designation Court of Appeal and keeps part of the Norwegian name Borgarting.

In the German translation the candidate has opted for the designation of a functional comparable court, followed by the original Norwegian designation. In the case of nächsthöheres Gericht in Oslo (Borgarting lagmannsrett) the candidate has opted for a description of the court structure by rendering lagmannsrett with nächsthöheres Gericht.

There is evidence that the combination of keeping the original designation and providing a translation is usually followed in e.g. books/articles on comparative law. However it can be discussed what would be the most appropriate word order. The German foreign ministry (Auswärtiges Amt) recommends on its homepage that the original designation of the German court "in principal" should be added in brackets after the translation. ${ }^{10}$

Given the text type here - a judicial decision - an overt translation (House 1997) should in my view, include both the original designation in case of needed reference as well as an explicative designation based on the reader's/recipient's world knowledge of his/her legal system which (s)he is expected to be familiar with. The translation is a secondary text to help understanding of the original.

(2) German translation of Folkeregistermyndigheita

In another text knowledge about the incongruity of the tasks of the Folkeregistermyndigheita (literally: 'population register authority') with those of the German Einwohnermeldeamt once again shows the translator's lacking insight into the structure of the particular authorities in the Norwegian and German legal cultures and their particular tasks. In this text the Norwegian registration authority has to decide whether the

10 http://www.auswaertigesamt.de/cae/servlet/contentblob/373544/publicationFile/181422/ Gerichtsbezeichnungen.pdf 
legal requirements for sharing the motherhood of a child in a same-sex marriage/cohabitation where the child was conceived after assisted reproductive technology treatment are met. The task of the Einwohnermeldeamt on the other hand is the residence registration, and has no comparable task to the Norwegian authority as described. German law ${ }^{11}$ does not (yet) recognise same-sex marriages and accordingly the ensuing problems with (registration of) motherhood etc. are non-existent. So the candidate should try to find a "neutral" designation for the particular authority (Šarčević 1990: 156). ${ }^{12}$

\subsection{German translation of specific legal terms - lack of background knowledge}

The following short comments deal with poor decisions on how to translate specific legal terms that stem from other legal texts:

(1) hovedforhandling: Hauptverhandlung vs. Haupttermin. The candidates show lack of awareness of the differences between civil and criminal procedure. Hauptverhandlung is only correct when referring to criminal procedure.

(2) generalforsamling: Generalversammlung instead of Hauptversammlung in the context of the German Stock Corporation Act (Aktiengesetz). This comment is valid only as long as the candidate has not indicated that (s)he translates into Swiss German or Austrian German which (s)he is asked to inform about.

(3) forskrift: Verordnung vs. Vorschrift. The literal translation with Vorschrift is a false friend. The candidates are assumed to know the hierarchy of legal rules (lex superior principle) where the constitution is the highest legal source (in the national legal system) followed by an act of Parliament and then a regulation (Verordnung) etc.

Even though the few examples above only refer to single terms, the candidate's wrong choice reveals that (s)he lacks the required knowledge on the topic at hand in the legal domain. Such examples represent useful examples to discuss with our JurDist candidates in order for them to avoid potential pitfalls and most importantly to raise their awareness about the need to increase their knowledge of the subject domains. My conclusion from experience of assessing many translations is that a vast majority of errors cannot be ascribed to the candidates' linguistic deficiency but rather to a lack of knowledge of the particular subject domains. JurDist is therefore largely content based providing a solid basis for the translation activities to be followed next spring.

\subsection{Observing style conventions}

One good example is the style convention for citing a particular provision, e.g. das Norwegische Gerichtsverfassungsgesetz § 169, Glied [sic!] 3, where the candidate follows the Norwegian convention of first mentioning the statute, and where the German

11 In the UK in August 2013 the "Marriage (Same Sex Couples) Act 2013 was enforced, but there is no parallel provision to the Norwegian one about the so called co-motherhood.

12 Šarčević argues that when there is no functional equivalent (Entsprechung) in the target legal culture, then the translator should use a neutral target oriented equivalent (neutrale $Z S$ Entsprechung) (op.cit.: 158). 
style conventions request first mentioning the section, then the name of the particular statute: $\S 169$ Abs. 3 Norwegisches Gerichtsverfassungsgesetz, and where I would suggest the addition of the name of the Norwegian statute (domstolloven) for the sake of reference in brackets after the translation. The English style conventions also differ (Wikipedia and Lind 2003: 203) and should be followed as closely as possible, ${ }^{13}$ e.g. where Norwegian and German legal texts use the sign '§', the English legal texts use 'section'.

\section{CONCLUDING REMARKS AND OUTLOOK}

The aim of this paper has been to discuss challenges in legal translation from the view of a teacher evaluating the work of semi-professional translators in a special setting with the aim of using recurrent errors as a pedagogical resource for JurDist and other translation candidates. The empirical findings were given to illustrate some typical challenges a translator is confronted with, e.g. culture-bound legal terms and specific legal terms as well as one particular type of style convention. A lack of knowledge of the particular subject domains has proven to be one of the most demanding challenges. Teaching different strategies to cope with such challenges is therefore central in our on-line course in legal translation.

\section{References}

BUSSE, Dietrich (2000) "Textsorten des Bereichs Rechtswesen und Justiz." In: K. Brinker et al. (eds), Text- und Gesprächslinguistik. - Ein internationales Handbuch zeitgenössischer Forschung. Vol. 1. Berlin/New York: de Gruyter, 658-675.

CHROMA, Marta (2008) "Semantic and Legal Interpretation: Two Approaches to Legal Translation." In: V. K. Bhatia/C. N. Candlin/P. E. Allori (eds), Language, Culture and the Law. The Formulation of Legal Concepts across Systems and Cultures. Bern etc.: Lang, 303-333.

GÉMAR, Jean-Claude (1988) "La traduction juridique: Art ou technique d'interprétation?" Meta 33/2, 305-319.

GISLE, Jon et al. (eds) (2010) Jusleksikon [Engelske termer ved Åge Lind]. Oslo: Kunnskapsforlaget.

GRUNTAR JERMOL, Ada (2012) "Übersetzen von Rechtstexten - einige didaktische Hinweise." Lebende Sprachen 57/1, 53-73.

HARVEY, Malcom (2002) "What's so Special about Legal Translation?" Meta 47/2, $177-185$.

HAU, Volker (2011) "Recent German reforms of civil procedure." In: V. Lipp/H. H. Fredriksen (eds), Reforms of Civil Procedure in Germany and Norway. Tübingen: Mohr Siebeck, 61-69.

HICKEY, Leo (ed.) (1998) The Pragmatics of Translation. Clevedon: Multilingual Matters.

13 For further details about the syntactic structures with respect to English legal text, see Hiltunen (2012). 
HILTUNEN, Risto (2012) "The Grammar and Structure of Legal Texts." In: P. M. Tiersma/L. M. Solan (eds), 39-51.

HJORT-PEDERSEN, Mette/Dorrit FABER (2005) "Legal Translation Training and Recognition of Information Needs. Or: Should the teaching of subject matter content be a thing of the past?" LSP \& Professional Communication. An International Journal 5/1, 42-54.

HOUSE, Juliane (1997) Translation Quality Assessment - A Model Revisited. Tübingen: Narr.

ISO 1087-1 (2000) Terminology work - Vocabulary - Part 1: Theory and application.

LIND, Åge ( $\left.{ }^{4} 2003\right)$ Norsk-engelsk juridisk ordbok. Sivil- og strafferett. Oslo: Appelen Akademisk Forlag.

LÖRSCHER, Wolfgang (1991) Translation Performance, Translation Process and Translation Strategies: A Psycholinguistic Investigation. Tübingen: Narr.

MATTILA, Heikki E.S. (22013 [2006]) Comparative Legal Linguistics. Language of Law, Latin and Modern Lingua Francas. Translated by Christopher Goddard. London: Ashgate.

NEUBERT, Albrecht (2000) "Competence in Language, in Languages, and in Translation.” In: C. Schäffner/B. Adab (eds), Developing Translation Competence. Amsterdam/Philadelphia: Benjamins, 3-18.

NORD, Christiane (1997) Translating as a Purposeful Activity. Functionalist Approaches Explained. Manchester: St. Jerome.

REISS, Katharina (1969): "Textbestimmung und Übersetzungsmethode. Entwurf einer Texttypologie." Ruperto-Carola 21/46, 69-75.

ŠARČEVIĆ, Susan (1990) "Strategiebedingtes Übersetzen aus den kleineren Sprachen im Fachbereich Jura." Babel 36/3, 155-166.

ŠARČEVIĆ, Susan (22000 [1997]) New Approach to Legal Translation. The Hague etc.: Kluwer Law International.

SCHÄFFNER, Christina (1998) "Parallel Texts in Translation." In: L. Bowker et al. (eds), Unity in Diversity? Current Trends in Translation Studies. Manchester: St. Jerome, 83-90.

SIMONNÆS, Ingrid (2005) "Das Übersetzen von Rechtstexten: Verstehen und Textanalyse." LSP \& Professional Communication 5/1, 55-74. [Reprinted in Simonnæs 2012].

SIMONNÆS, Ingrid (2006) 'Zum 'Zweck' im Recht und in der Übersetzungswissenschaft." In: C. Heine/K. Schubert/H. Gerzymisch-Arbogast (eds), Text and Translation. Theory and Methodology of Translation. Tübingen: Narr, 67-78 [reprint in Simonnæs 2012].

SIMONNÆS, Ingrid (2012) Rechtskommunikation national und international im Spannungsfeld von Hermeneutik, Kognition und Pragmatik. Berlin: Frank \& Timme.

SUNDE, Jørn Øyrehagen (2010) "Champagne at the Funeral - an Introduction to Legal Culture.” In: J. Ø. Sunde/K. E. Skodvin (eds), Rendezvous of European Legal Cultures. Bergen: Fagbokforlaget, 11-28. 
TIERSMA, Peter (s.a.) The Creation, Structure, and Interpretation of the Legal Text. http://www.languageandlaw.org/LEGALTEXT.HTM [15 March 2013].

TIERSMA, Peter M./Lawrence M. SOLAN (eds) (2012) The Oxford Handbook of Language and Law. Oxford: Oxford University Press.

VANDERLINDEN, Jacques (1999) "Langue et Droit." In: E. Jayme (ed.), Langue et Droit. XVe Congrès International de Droit Comparé. Bristol 1998. Collection des rapports. Bruxelles: Bruylant, 65-122.

VERMEER, Hans J. (1978) "Ein Rahmen für eine allgemeine Translationstheorie." Lebende Sprachen 23/3, 99-102.

Auswärtiges Amt. 10 October 2013. http://www.auswaertigesamt.de/cae/servlet/contentblob/373544/publicationFile/181422/Gerichtsbezeichnungen.pdf.

Merriam Webster Dictionary. 10 October 2013. http://www.merriam-webster.com/ dictionary.

The Courts of Justice. 10 October 2013. http://www.domstol.no/en/The-Courts-of-Justice/.

National Translator Accreditation Exam. 10 October 2013. http://www.nhh.no/en/ research-faculty/department-of-professional-and-intercultural-communication/ statsautorisert-translatøreksamen/the-national-translator-accreditation-exam. aspx.

Norwegian Agricultural Authority. 10 October 2013. https:/www.slf.dep.no/en/property/allodialrights;jsessionid=236EF550C8E617DE75C4F3889495BFBF\#sever al-sets-of-rules.

Translated Norwegian Legislation. 10 October 2013. http://www.ub.uio.no/cgi-bin/ ujur/ulov/sok.cgi?type=LOV.

\section{Abstract \\ CHALLENGES IN LEGAL TRANSLATION - REVISITED}

The aim of this paper is to discuss challenges in legal translation from the view of a teacher who evaluates the work of semi-professional translators in a special setting. Recurrent translation errors may subsequently be used as a pedagogical resource in specialised translator training. The observation of recurrent challenges confronting the candidates in legal translation and the absence of formal translator training programs are the reasons why NHH now offers an on-line course in legal translation, JurDist, focusing i.a. on useful translation strategies.

Keywords: functionalist approach, legal terminology, translation error, translation strategies, on-line course in legal translation. 
Namen članka je predstaviti izzive pri prevajanju pravnih besedil, s katerimi se srečuje učitelj pri ocenjevanju dela polprofesionalnih prevajalcev v posebnem okolju. Ponavljajoče se prevajalske napake lahko pozneje služijo kot pedagoški pripomoček pri izobraževanju prevajalcev za specialna področja. Ker se kandidati pri pravnem prevajanju vedno srečujejo z novimi izzivi in dilemami in ker manjka formalnih izobraževalnih programov za prevajalce, se je Norveška ekonomska fakulteta (NHH) odločila vpeljati spletni tečaj pravnega prevajanja JurDist, ki se posveča uporabnim prevajalskim strategijam.

Ključne besede: funkcionalistični pristop, pravna terminologija, prevodna napaka, prevodne strategije, spletni tečaj pravnega prevajanja. 